\title{
BM] Global Health Reimagining global health systems for the 21st century: lessons from the COVID-19 pandemic
}

\author{
Yibeltal Assefa (D) , ${ }^{1}$ Charles F Gilks, ${ }^{1}$ Remco van de Pas (D),${ }^{2}$ Simon Reid, ${ }^{1}$ \\ Dereje Gedle Gete, ${ }^{1}$ Wim Van Damme ${ }^{2}$
}

\begin{abstract}
To cite: Assefa Y, Gilks CF, van de Pas $\mathrm{R}$, et al. Reimagining global health systems for the 21st century: lessons from the COVID-19 pandemic. BMJ Global Health 2021;6:e004882. doi:10.1136/ bmjgh-2020-004882
\end{abstract}

Handling editor Seye Abimbola

Received 28 December 2020 Revised 16 April 2021 Accepted 17 April 2021
Check for updates

C) Author(s) (or their employer(s)) 2021. Re-use permitted under CC BY-NC. No commercial re-use. See rights and permissions. Published by BMJ.

${ }^{1}$ School of Public Health, The University of Queensland, Brisbane, Queensland, Australia ${ }^{2}$ Department of Public Health, Institute of Tropical Medicine, Antwerp, Belgium

Correspondence to Dr Yibeltal Assefa; y.alemu@uq.edu.au

\section{THE COVID-19 PANDEMIC: A REMINDER FOR A STRONG GLOBAL HEALTH SYSTEM}

The COVID-19 pandemic is a timely reminder of the nature and impact of global health threats that could become Public Health Emergency of International Concern (PHEIC). ${ }^{1}$ The virus has spread quickly to all countries (although with variable epidemiological patterns), and has overwhelmed even some of the most advanced health systems. ${ }^{2}$ As of 12 April 2021, the pandemic has caused more than 136 million cases and 2.93 million deaths. ${ }^{3}$ But beyond morbidity and mortality, it affects the whole of society and government, and causes serious socioeconomic loss. ${ }^{4-6}$ With the emergence and spread of new variants of the virus, ${ }^{7}$ it is highly likely that the virus will be circulating and staying with us for the foreseeable future. The longer and the more severe the pandemic, the greater are the social and economic disruptions and the political challenges. ${ }^{8}$

The COVID-19 pandemic spread throughout the world due to inadequate preparedness for global health security (GHS). ${ }^{9}$ The spread and consequence of the virus is intensified by gaps in the implementation of the programmes in the third Sustainable Development Goal, ${ }^{10}$ including universal health coverage (UHC), ${ }^{11}$ and tension between UHC and GHS. ${ }^{12} 13$ The pandemic demonstrates that health security is not only a national but also a regional and global common good. ${ }^{14}$ It substantiates that the world urgently needs a strong global health system, including global, regional and national actors with collective responsibility and mutual accountability. It also highlights the need for robust systems to respond more effectively to the inevitable future global health challenges. ${ }^{15} \mathrm{~A}$ strong global health system is vital to tackle current and future PHEIC. ${ }^{16}$
Summary box

The COVID-19 pandemic is a timely reminder of the nature and impact of public health emergencies of international concern; the pandemic demonstrates that the world needs a strong global health system now more than ever.

- The aspiration to build a strong global health system can be realised with a paradigm shift from nationalism and self-reliance to multilateralism, shared responsibility, and mutual accountability among countries and regions.

- A strong global health system requires technical awareness and political will towards universal health coverage and health security at national, regional and global levels, including the richest and most powerful countries.

- Countries (individually and collectively) should have a coherent and context-specific national strategy, build the capacity of their health systems, minimise fragmentation, improve governance and tackle upstream structural issues, including socioeconomic inequities.

\section{WHY SHOULD COUNTRIES DO MORE TOWARDS A} STRONG GLOBAL HEALTH SYSTEM?

Countries have several incentives to plan and act locally, regionally and globally towards a strong global health system that can prevent, detect and respond to PHEIC. Pandemics not only cost lives but also pose some of the greatest risks to the global economy and security. ${ }^{17}$ As the world's population becomes more mobile and interdependent, and with biodiversity reduction and ecological degradation, global health threats increase and traditional defences at national borders cannot protect people against the invasion of a disease or vector. ${ }^{18}$

We argue that countries have at least three foreign policy imperatives why they should cooperate more intensively on global health; namely for security, economic and moral 
reasons ${ }^{19}$ Health security risks can easily be transmitted from one place to another. ${ }^{2021}$ The benefits of investments for GHS in one country often extend to the wider region or the globe. ${ }^{22}$ The implication is that health security requires a regional and global level response, management and coordination. ${ }^{23} 24$

On the other hand, the impact of a pandemic extends much beyond mortality and causes serious socioeconomic losses. The spread of the virus triggered lockdowns which have sparked fears of an impending financial and debt crisis. ${ }^{4}$ Many have lost their jobs, which pose increased dependency and pose social insecurity. ${ }^{5}$ The COVID-19 pandemic has disrupted the functioning of global supply chains, heightened uncertainty in consumption and investment and international trade, ${ }^{25}$ resulting in shortages of goods across the world. ${ }^{6}$ Social distancing, selfisolation and travel restrictions have led to a reduced employment across many economic sectors. ${ }^{17}$ Overall, the COVID-19 pandemic impacts economies. ${ }^{26}$ As a result, governments have strengthened institutions that facilitate international trade and relations or, on the contrary, may become increasingly isolationist, avoiding international cooperation. ${ }^{27}$

Countries do also have a moral obligation in the prevention and control of PHEIC. As the COVID-19 pandemic has demonstrated, when a disease with pandemic potential emerges, neighbouring countries (bordering states) and those well integrated in the globalised economy (mainly high-income countries (HICs) and middleincome countries (MICs)) are the first to be impacted by the epidemic after the country of origin. Low-income countries (LICs) will only afterwards be affected by the pandemic, which raises a lot of concern in LICs as they have weak health systems and often limited social protection mechanisms. Such rapid viral spread is related to the globalised economies and population mobility for which HICs and MICs play a significant role. This global interconnection implies that HICs and MICs do have a historical and moral responsibility to support initiatives for the preparedness, prevention, detection and response of the pandemic in LICs. This is somehow similar to the climate emergency which is affecting LICs despite the fact that HICs and MICs have historically contributed to most of the greenhouse gas emissions, causing climate change. This demands 'common but differentiated responsibilities' that impose obligations more heavily on wealthier nations than on others. ${ }^{28}$

\section{WHAT SHOULD BE DONE TO STRENGTHEN THE GLOBAL HEALTH SYSTEM?}

The aspiration towards a safer world will be realised only if all countries have not only strong essential capacities for implementing the International Health Regulations (IHRs), but also health systems for UHC and realise strong synergy between IHR (GHS) and UHC. ${ }^{11}$ Compliance with the IHR is a critical step towards an effective response to epidemics (and pandemics) ${ }^{29}$; on the other hand, UHC is crucial to establish a first line of defence against threats to health, ${ }^{30}$ and to enable all people to 'obtain the health services they need without suffering financial hardship when paying for them'. ${ }^{32}$

COVID-19 demonstrates that health security is a local, regional and global common good, ${ }^{33}$ which requires not only an individual action but also a collective response ${ }^{14}$ that is possible if there is adequate technical capacity and political will not only at local and national but also at regional and global levels. This thus requires multilevel governance arrangements that coordinate actions at local (subnational), national, regional and global levels. ${ }^{34}$

\section{Local and national}

The pandemic reveals that all countries around the world should build their IHRs' core capacities and health systems according to the primary healthcare approach. ${ }^{3536}$ There is an urgent need to further increase investments in comprehensive public health programmes. ${ }^{37}{ }^{38}$ This is possible only if countries have a coherent and contextspecific national strategy that guides alignment of investments from external support with local resources. It is also vital that disease control activities are integrated with other health services at the primary healthcare level to minimise fragmentation, and that sufficient health workers are recruited and retained. ${ }^{37}$ For instance, there are substantial opportunities, including integration and linkage, for synergies in the delivery of care for people with HIV/AIDS and non-communicable diseases. ${ }^{39}$ This opportunity should be leveraged to increase effectiveness, efficiency, responsiveness and health outcomes.

The response to COVID-19 reveals that the management of PHEIC requires proactive and prompt leadership. There are lessons on this around the world. For instance, Vietnam and many Asian countries, with recent experiences of the SARS pandemic to guide them, were extremely successful in dealing with the pandemic. Vietnam quickly recognised the devastating nature of the pandemic and acted early. The government created a National Steering Committee chaired by the viceprime minister, with a clear structure at the start of the pandemic, and adopted an approach of transparency in reporting information about the COVID-19 epidemic. ${ }^{40}$ Politics has been at the core of how governments have prepared for and responded to the COVID-19 crisis. ${ }^{41}$ The responses to COVID-19 demonstrate that technical solutions require political decisions. The governments of HICs with a successful response to COVID-19 exhibit the key characteristics of justice and comprehensive public health: governing for the common good; shared and clear responsibilities between different actors; rational, compassionate and transparent communication; and legitimate leadership and trust. ${ }^{42}{ }^{43}$ The response to the pandemic should be guided by governance, which is balancing both sound analysis and decision speed, centralised and decentralised decision-making, societal deliberation and participatory representation, innovation and bureaucracy, and science and politics. ${ }^{44}$ 
Certain population groups, including the elderly, suffer a disproportionate share of severe disease and death. ${ }^{45} 46$ Countries should apply the principles of precision public health by investing in data systems and people-centred delivery platforms. The COVID-19 pandemic illustrates how utterly unprepared certain countries were for such approach to disease control. Precision public health helps to more granularly predict and understand risks and customise treatments for more specific and homogeneous subpopulations. ${ }^{47}$ Adequately disaggregated data, used responsibly, are necessary to design effective strategies that aim to reduce the risk of transmission in vulnerable populations. ${ }^{48}{ }^{49}$ A detailed assessment of the number of at-risk individuals can inform possible shielding strategies. ${ }^{48}$

COVID-19 has been a stress test for public services and social protection systems. Surveillance is key: the health of vulnerable and marginalised groups must be regularly monitored and reported transparently. Universal systems must be sensitive to differences in population groups, identify and remove barriers to accessing essential services. Countries with strong social protection systems have been able to respond rapidly to epidemics, meet sudden surges in demand for services, maintain universal access, and deal with population-specific and locationspecific challenges.

\section{Regional and global}

In a hyperconnected and densely populated continent, such as Europe, control measures across borders have to be better coordinated. This arrangement requires a broader strategy (whole of government) and societal consensus (whole of society) on ways to deal with such a crisis, in which timely measures and collective adherence are crucial. ${ }^{50}{ }^{51}$ There are lessons from African countries which have managed to coordinate the response at both national and continental levels. ${ }^{52}$ African countries came together and created task forces to improve and strengthen their responses against COVID-19.53

The response to pandemics could be enhanced through strengthening systems towards GHS and UHC. However, LICs still require financial support to build their core capacities and health systems, designed according to the primary healthcare approach for a comprehensive public health. ${ }^{35} 3643$ It is in the interest of HICs and MICs to provide support to strengthen the capacity of essential public health functions in LICs. ${ }^{22}$ HICs should continue to deliver their international assistance responsibility and cooperation obligations such as IHR. ${ }^{54}$ The COVID-19 pandemic urges countries to reshape their collective actions and international assistance for global common good. The pandemic can be an opportunity to reset global health governance and financing. ${ }^{55}$ This opportunity can be seized if we build a sense of collective identity and develop collective action to address the multiple factors affecting global health. Such a global health finance framework would have to include components of a multinational taxation system, a financing pool for global common good as well as a strong multilateral regulatory and institutional agency such as an autonomous and well-funded WHO. ${ }^{56}$

HICs can also support the production and procurement of vaccines in MICs. Mechanisms such as parallel importation and voluntary licences, or even a temporary Trade-Related Aspects of Intellectual Property Rights waiver for the time of the pandemic, such as proposed by South Africa and India, could facilitate that. ${ }^{57}$ MICs can use their pharmaceutical infrastructure to produce vaccines to reach the needs of several billions. There are lessons that could be learnt from other global health programmes for increased production of vaccines and therapeutics. For instance, voluntary licensing for the production of HIV antiretrovirals (ARVs) has demonstrated that these mechanisms facilitated the scale-up of ARV manufacturing in India and other MICs. This led to significant price reductions and a massive increase in access to affordable products in low/middle-income countries (LMICs) ${ }^{58}$ Providing voluntary licensing for the production of vaccines, such as via WHO's COVID-19 Technology Access Pool (C-TAP), will have a similar effect in increasing access to the vaccines in LMICs. ${ }^{59}$

HICs can also do more in research and development. Interdisciplinary understanding and engagement, which is even much more than multidisciplinary approach, is vital for effective control of the pandemic. ${ }^{60}$ Social science research, including political science, sociology, psychology, anthropology and economics, is vital to help understand why some communities, countries or regions have managed to control their epidemics better than others. ${ }^{61}$ Innovative studies are also needed to investigate why some people have more effective responses than others so that we can better prevent and treat disease. ${ }^{62}$ Efforts to gear up biomedical research and quickly develop new vaccines and therapeutics obviously are of utmost importance.$^{63}$ It is commendable that HICs are supporting the implementation of the COVID-19 Global Research Roadmap to guide a united COVID-19 agenda for research and development. ${ }^{64}$ It is of utmost importance to develop a framework for equitable, practical and ethical distribution of vaccines. ${ }^{65}$ Financial and political commitment by HICs to WHO's Access to COVID-19 Tools-Accelerator, the related COVAX global vaccine facility as well as the above mentioned C-TAP are crucial in the fair distribution of vaccines and other COVID-19 tools. ${ }^{66}$

\section{CONCLUSION}

The COVID-19 pandemic is a timely reminder of the nature and impact of PHEIC and their inevitability. The pandemic demonstrates that the world needs a strong global health system now more than ever. The aspiration to build a strong global health system can be realised with a paradigm shift from nationalism and self-reliance to multilateralism, shared responsibility, sovereignty, strategic dependency, and mutual accountability among 
countries and regions. We argue that the global health community can progressively strengthen the global health system through actions at national, regional and global levels. This is possible if all countries, individually and collectively, have the technical awareness and political will towards UHC and health security globally, including the richest and most powerful countries.

Twitter Dereje Gedle Gete @DerejeGedle

Contributors YA conceptualised the commentary, and wrote the first and subsequent drafts. CFG, RvdP, DG, SR and WVD provided comments during subsequent drafts. All authors approved the final version of the manuscript for submission.

Funding The authors have not declared a specific grant for this research from any funding agency in the public, commercial or not-for-profit sectors.

Competing interests None declared.

Patient consent for publication Not required.

Provenance and peer review Not commissioned; externally peer reviewed.

Data availability statement Data are available in a public, open access repository.

Open access This is an open access article distributed in accordance with the Creative Commons Attribution Non Commercial (CC BY-NC 4.0) license, which permits others to distribute, remix, adapt, build upon this work non-commercially, and license their derivative works on different terms, provided the original work is properly cited, appropriate credit is given, any changes made indicated, and the use is non-commercial. See: http://creativecommons.org/licenses/by-nc/4.0/.

\section{ORCID iDs}

Yibeltal Assefa http://orcid.org/0000-0003-2393-1492

Remco van de Pas http://orcid.org/0000-0002-6098-334X

\section{REFERENCES}

1 El Zowalaty ME, Järhult JD. From SARS to COVID-19: A previously unknown SARS- related coronavirus (SARS-CoV-2) of pandemic potential infecting humans - Call for a One Health approach. One Health 2020;9:100124.

2 Van Damme W, Dahake R, Delamou A, et al. The COVID-19 pandemic: diverse contexts; different epidemics-how and why? BMJ Glob Health 2020;5:e003098.

3 Our World in Data. Coronavirus pandemic (COVID-19), 2021. Available: https://ourworldindata.org/coronavirus [Accessed 8 Mar 2021].

4 Oldekop JA, Horner R, Hulme D, et al. COVID-19 and the case for global development. World Dev 2020;134:105044.

5 Stanley C, Nkporbu A, Stanley P. Socio-Economic implications of the coronavirus pandemic: early review and projections, Nigeria in focus.

6 Baker SR, Bloom N, Davis SJ, Kost KJ, Sammon MC, Viratyosin

T. The unprecedented stock market impact of COVID-19: national Bureau of economic research; 2020.

7 Tang JW, Tambyah PA, Hui DS. Emergence of a new SARS-CoV-2 variant in the UK. J Infect 2021;82:e27-8.

8 Gruszczynski L. The COVID-19 pandemic and international trade: temporary turbulence or paradigm shift? European Journal of Risk Regulation 2020;11:1-6

9 Assefa Y, Hill PS, Gilks CF, et al. Global health security and universal health coverage: understanding convergences and divergences for a synergistic response. PLOS One 2020;15:e0244555.

10 50/50. GH. The global health 50/50 report 2020: power, privilege and priorities; 2020.

11 World Health Organization (WHO). Thirteenth General programme of work 2019-2023. The seventy-first World health assembly. Geneva, Switzerland: World Health Organization, 2018.

12 Ooms G, Beiersmann C, Flores W, et al. Synergies and tensions between universal health coverage and global health security: why we need a second 'Maximizing Positive Synergies' initiative. BMJ Glob Health 2017;2:e000217.

13 Ooms G, Ottersen T, Jahn A, et al. Addressing the fragmentation of global health: the Lancet Commission on synergies between universal health coverage, health security, and health promotion. Lancet 2018;392:1098-9.
14 Katz R, Standley CJ. Regional approaches for enhancing global health security. BMC Public Health 2019:19:473.

15 van de Pas R, Ooms G. Giving hope a sporting chance: COVID-19 as a beneficial epidemic? BMJ Glob Health 2021;6:e005784.

16 Bennett B, Carney T. Public health emergencies of international concern: global, regional, and local responses to risk. Med Law Rev 2017;25:223-39.

17 Nicola M, Alsafi Z, Sohrabi C, et al. The socio-economic implications of the coronavirus pandemic (COVID-19): a review. Int J Surg 2020;78:185-93.

18 World Health Organisation (WHO). Health security, 2020. Available: https://www.who.int/health-topics/health-security/\#tab=tab 1

19 Labonté R, Gagnon ML. Framing health and foreign policy: lessons for global health diplomacy. Global Health 2010;6:14.

20 Beck U. From industrial Society to the risk society: questions of survival, social structure and ecological enlightenment. Theory, Culture Soc 1992;9:97-123.

21 Risk JDS. Globalisation and the state: a critical appraisal of Ulrich Beck and the world risk society thesis. Global society 2007;21:23-46.

22 Brown T. 'Vulnerability is universal': considering the place of 'security' and 'vulnerability' within contemporary global health discourse. Soc Sci Med 2011;72:319-26.

23 Gostin LO, Katz R. The International health regulations: the governing framework for global health security. Milbank $Q$ 2016;94:264-313.

24 Moon S, Sridhar D, Pate MA, et al. Will Ebola change the game? Ten essential reforms before the next pandemic. The report of the Harvard-LSHTM independent panel on the global response to Ebola. The Lancet 2015;386:2204-21.

25 Ozili PK, Arun T. Spillover of COVID-19: impact on the global economy. SSRN Journal 2020;10.

26 Barua S. Understanding Coronanomics: the economic implications of the coronavirus (COVID-19) pandemic. SSRN Electronic Journal 2020;21.

27 Kerr WA. The COVID-19 pandemic and agriculture-Short and long run implications for international trade relations. Can J Agric Econ 2020.

28 Stone CD. Common but differentiated responsibilities in international law. American Journal of International Law 2004:276-301.

29 Wilson K, von Tigerstrom B, McDougall C. Protecting global health security through the International health regulations: requirements and challenges. CMAJ 2008;179:44-8.

30 Wenham C, Katz R, Birungi C, et al. Global health security and universal health coverage: from a marriage of convenience to a strategic, effective partnership. BMJ Glob Health 2019;4:e001145.

31 World Health Organization (WHO). Guinea: the Ebola virus shows its Tenacity, 2015. Available: http://www who int/csr/disease/ebola/ one-year-report/guinea/en/

32 O'Connell T, Rasanathan K, Chopra M. What does universal health coverage mean? The Lancet 2014;383:277-9.

33 Smith RD. Global public goods and health. SciELO Public Health, 2003.

34 Kickbusch I, Szabo MMC. A new governance space for health. Glob Health Action 2014;7:23507.

35 Bloom G. Universal Health Coverage and Primary Healthcare: Lessons From Japan Comment on "Achieving Universal Health Coverage by Focusing on Primary Care in Japan: Lessons for Low- and Middle-Income Countries". Int J Health Policy Manag 2017;6:229-31.

36 Binagwaho A, Adhanom Ghebreyesus T, Ghebreyesus TA. Primary healthcare is cornerstone of universal health coverage. $B M J$ 2019;365:I2391.

37 Balabanova D, McKee M, Mills A, et al. What can global health institutions do to help strengthen health systems in low income countries? Health Res Policy Syst 2010;8:22.

38 Mahjour J, Mirza Z, Rashidian A, et al. "Promote health,keep the world safe,serve the vulnerable" in the Eastern Mediterranean Region. East Mediterr Health J 2018;24:323-4.

39 Watkins DA, Tulloch NL, Anderson ME, et al. Delivery of health care for cardiovascular and metabolic diseases among people living with HIV/AIDS in African countries: a systematic review protocol. Syst Rev 2016;5:63.

40 Trevisan M, LC L, AV L. The COVID-19 pandemic: a view from Vietnam. American Public Health Association, 2020.

41 Davies SE, Wenham C. Why the COVID-19 response needs international relations. Int Aff 2020;96:1227-51.

42 Ruger JP. Social justice as a foundation for democracy and health. BMJ 2020;371:m4049.

43 Loewenson R, Accoe K, Bajpai N, et al. Reclaiming comprehensive public health. BMJ Glob Health 2020;5:e003886. 
44 Janssen $\mathrm{M}$, van der Voort $\mathrm{H}$. Agile and adaptive governance in crisis response: lessons from the COVID-19 pandemic. Int $J$ Inf Manage 2020;55:102180.

45 Graham NSN, Junghans C, Downes R, et al. SARS-CoV-2 infection, clinical features and outcome of COVID-19 in United Kingdom nursing homes. J Infect 2020;81:411-9.

46 McMichael TM, Clark S, Pogosjans S, et al. COVID-19 in a LongTerm Care Facility - King County, Washington, February 27-March 9 , 2020. MMWR Morb Mortal Wkly Rep 2020;69:339-42.

47 Dolley S. Big data's role in precision public health. Front Public Health 2018;6:68.

48 Banerjee A, Pasea L, Harris S, et al. Estimating excess 1-year mortality associated with the COVID-19 pandemic according to underlying conditions and age: a population-based cohort study. Lancet 2020;395:1715-25.

49 Davies NG, Klepac P, Liu Y, et al. Age-dependent effects in the transmission and control of COVID-19 epidemics. Nat Med 2020;26:1205-11.

50 Alemanno A. Towards a European health Union: time to level up. Eur J Risk Regulation 2020;11:721-5.

51 European Commission. Building a European Health Union: Reinforcing the EU's resilience for cross-border health threats, 2020 Available: https://eur-lex.europa.eu/legal-content/EN/TXT/PDF/?uri= CELEX:52020DC0724\&from=EN [Accessed 23 Dec 2020].

52 Nkengasong JN, Mankoula W. Looming threat of COVID-19 infection in Africa: act collectively, and fast. The Lancet 2020;395:841-2.

53 Osseni IA. COVID-19 pandemic in sub-Saharan Africa: preparedness, response, and hidden potentials. Trop Med Health 2020;48:1-3.

54 Bueno De Mesquita J, Mason Meier B. Moving towards global solidarity for global health through multilateral governance in the COVID-19 response, 2020.
55 Yamey G, Jamison D, Hanssen O, et al. Financing global common goods for health: when the world is a country. Health Syst Reform 2019;5:334-49.

56 Soucat A, Kickbusch I. Global common goods for health: towards a new framework for global financing, 2020.

57 Tejomurti K, Pujiyono P, Pranoto P. Application of parallel importation and voluntary license in the Covid-19 vaccines patent as a strategy for handling the health emergency situations in Indonesia. Hang Tuah Law Journal 2020;4:108-19.

58 Hill AM, Pozniak AL. How can we achieve universal access to lowcost treatment for HIV? J Virus Erad 2016;2:193-7.

59 Usher AD. COVID-19 vaccines for all? The Lancet 2020;395:1822-3.

$60 \mathrm{Mol}$ A, Hardon A. What COVID-19 may teach us about interdisciplinarity. BMJ Glob Health 2020;5:e004375.

61 Wen J, Wang W, Kozak M. Many brains are better than one: the importance of interdisciplinary studies on COVID-19 in and beyond tourism. Tourism Recreat Res 2020;534:1-4.

62 Koff WC, Williams MA. Covid-19 and Immunity in Aging Populations - A New Research Agenda. N Engl J Med 2020;383:804-5.

63 Liu C, Zhou Q, Li Y. Research and development on therapeutic agents and vaccines for COVID-19 and related human coronavirus diseases. ACS Publications, 2020

64 World Health Organization. COVID 19 public health emergency of international concern (PHEIC). Global research and innovation Forum: towards a research roadmap, 2020.

65 Emanuel EJ, Persad G, Kern A, et al. An ethical framework for global vaccine allocation. Science 2020;369:1309-12.

66 World Health Organisation (WHO). COVID-19 technology access pool, 2020. Available: https://www.who.int/emergencies/diseases/ novel-coronavirus-2019/global-research-on-novel-coronavirus2019-ncov/covid-19-technology-access-pool [Accessed 23 Dec 2020]. 